\title{
The Impacts of Climate-Induced Agricultural Drought on Four Cereal Crops: A Case Study in Bako Tibe District, Oromia National Regional State, Ethiopia
}

\author{
Terefa Adunya ${ }^{1}$ and Fedhasa Benti ${ }^{2 *}$ \\ ${ }^{1}$ Department of Environmental Science, College of Natural and Computational Science, Ethiopia; \\ ${ }^{2}$ Energy and Environmental Research Center, Wollega University, Ethiopia \\ ${ }^{*}$ Corresponding author: fedeesa@ gmail.com
}

\begin{abstract}
Increasing temperature and altered precipitation patterns lead to the extreme weather events such as drought and flood, which severely affects the agricultural production. This study was aimed to assess the impact of climate change-induced agricultural drought on four cereal crops in Bako Tibe District. Time-series climate and crop yield data, recorded from 1989 to 2018, were acquired from NASA's data portal and Bako Research Institute. The changes in temperature and precipitation were analyzed using Mann Kendall trend test. The agricultural drought index was analyzed using R-software. The correlation between the selected yield crops and drought indices were evaluated using Pearson correlation coefficient. The results show that trends of seasonal and annual maximum and minimum temperatures were significantly increased $(\mathrm{P}<0.05)$. However, seasonal and annual precipitations were insignificantly decreased $(\mathrm{P}>0.05)$. Moderate to severe agricultural drought intensities happened four times in the last three decades. These drought spells spatially covered about $36 \%$ of the total area of the district. Crop yields and drought indices were significantly correlated at p-values; $0.0034,0.043,0.003$ and 0.001 for teff, wheat, barley and maize, respectively. The coefficient of determination (R2) values of crop yields were $28.3 \%, 30.9 \%, 28.5 \%$ and $34.6 \%$ for teff, wheat, barley and maize, correspondingly. The study clearly suggests that the increase in temperature and decrease in precipitation enhanced the frequency and intensity of drought events and these impacted the selected crop yields during the past three decades. The map-based results could be used as guides for governmental and non-governmental organizations concerning on drought impact mitigation activities in the district by encouraging farmers to adopt appropriate agricultural technologies, drought tolerant crop varieties and small scale irrigation.
\end{abstract}

Keywords: agricultural drought; climate change; coefficient determination; crop yield; precipitation temperature trends

Cite this as: Adunya T., \& Benti, F. (2020). The Impacts of Climate-Induced Agricultural Drought on Four Cereal Crops: A Case Study in Bako Tibe District, Oromia National Regional State, Ethiopian. Caraka Tani: Journal of Sustainable Agriculture, 35(1), 135-146. doi: http://dx.doi.org/10.20961/carakatani.v35i1.35749

\section{INTRODUCTION}

Climate change is the environmental challenge encountered by global societies. In the context of climate change, drought risks involving duration and intensity are likely to increase in many historical drought-prone regions including east Africa, at projected both $1.5^{\circ} \mathrm{C}$ and $2^{\circ} \mathrm{C}$ global warming (Sheffield and Wood, 2008; Brown et al., 2017; Liu et al., 2018). The risk of drought shows the increases in drought durations from 2.9 months to 3.2 months on a global scale and in several hotspot regions such as East Africa, Amazon, Northeastern Brazil, Southern and Central Europe at both $1.5^{\circ} \mathrm{C}$ and $2^{\circ} \mathrm{C}$ of global warming related to the historical period.

\footnotetext{
* Received for publication November 21, 2019 Accepted after corrections February 1, 2020
} 
In the east African countries, including Ethiopian, climate change and global warming coupled with anthropogenic ecological change effects significantly harmed the economy and livelihoods, lead to community conflicts (Black et al., 2011; Hendrix and Salehyan, 2012). Despite the lacks of contributions to the climate change or global warming, Ethiopian people are the victims of climate change as well as climate changeinduced extremes events (drought and floods) that are not their responsibilities. Current climate change-induced drought is already imposing at significant level on Ethiopian agricultural economy, water and natural resources, energy supply and sustainable development efforts (EPA, 2011). Drought and heat can reduce crop productivity and yield, leading to lower income of farmers. This reductions in crop yield will be further exacerbated by future climate change (Sheffield and Wood 2008; IPCC, 2014).

Crop model simulations indicated that between 1982 and 2014, parts of Eastern Amhara and Eastern Oromia experienced increasing water deficits during the critical sowing, flowering and ripening periods of crop growth (Brown et al., 2017). The livelihoods of large numbers of the rural community will be put at risk and vulnerability of crop production to climate change increase (IPCC, 2014). One of the influences of climate change on crop yields was worsening soil moisture stress during crop growing seasons (Kindu et al., 2016). Although higher temperatures can improve crop growth, studies have documented that crop yields decline significantly when daytime temperatures exceed a certain crop-specific level (Egal, 2019). Pollination is one of the most sensitive phenological stages to temperature extremes across all species and during this developmental stage, temperature extremes would greatly affect production (Hatfield and Prueger, 2015). Therefore, vulnerable areas are predicted to experience losses in agricultural productivity, primarily due to reductions in crop yields and ultimate effect goes to poorer condition. Accordingly, climate change is a major threat for sustainable agriculture in Ethiopia.

The issue of climate change and climate extremes has drawn a great attention from policy makers and academicians for last decades. In view of that, a number of studies have been done at regional and country levels to estimate the escalation of climate change and climate extremes. For instances, Diffenbaugh et al. (2007) studied on heat stress intensification in the Mediterranean climate change hotspot and reported that maximum and minimum temperature magnitude increased more than $75^{\text {th }}$ percentile magnitude. Smith (2011) conducted research on the ecological role of climate extremes and recounted severe drought, heat waves and periods of heavy rainfall, which can have profound consequences for both ecological systems and human welfare. Calanca (2007) studied on climate change and drought occurrence in the Alpine region and specified a 20\% decrease in the frequency of wet days with respect to the growing season of summer crop and the increase of drought from $15 \%$ to more than $50 \%$. Nevertheless, all these scientific studies are largely aggregated that but they have not revealed the economic impact climate change and climate extremes.

In the particular area of the present study, the farmers are suffering from climate changeinduced drought events. Nowadays, erratic and unreliable rainfall in the rainy seasons is common in the Bako Tibe District, resulting in drought, floods, land degradation and soil. In addition, the district is exposed to an increase in temperature, which upsurges heat waves that cause erosion. These varied climate variables in the study area influence the production and productivity of the farming community living the district. However, the intrinsic capacity of the climate system of the area to change temperature and precipitation, the severity of climate extremes (drought and wet) and its impacts on crop production have not yet thoroughly studied and documented in the district.

Therefore, all areas throughout Ethiopia, including the site of the study, are experiencing considerable annual regular period of dry season and drought is not a novel phenomenon. The real drought problem, however, arises when the rainfalls fail to fit with the normal cropping seasons. As this gap brings about eminent crop failure and high yield reduction, drought can be perceived as the quantitative, spatial and temporal mismatch between rainfall and the cropping season. Thus, this study aimed to explore the trends and variability of temperature and precipitation, intensity and spatiotemporal distribution of agricultural drought and its association with selected crop yields. Present study is highly significant for planning sustainable agricultural development and exploring climate 
change adaptation and mitigation strategies at farmers' level as well as for providing early warning system.

\section{MATERIALS AND METHOD}

\section{Location of study area}

The study was conducted in Bako Tibe District, which is one the 24 districts in West
Showa zone, Oromia National Regional state, Ethiopia. The district is located between $8^{\circ} 55^{\prime} 18^{\prime \prime}$ to $9^{\circ} 14^{\prime} 13^{\prime \prime} \mathrm{N}$ in latitude and $37^{\circ} 01^{\prime} 54^{\prime \prime}$ to $37^{\circ} 17^{\prime} 07^{\prime \prime} \mathrm{E}$ in longitude (Figure 1). The area is characterized by warm humid eco-climatic zone with annual mean temperature of $21^{\circ} \mathrm{C}$ and annual total rainfall of $1,260 \mathrm{~mm}$.

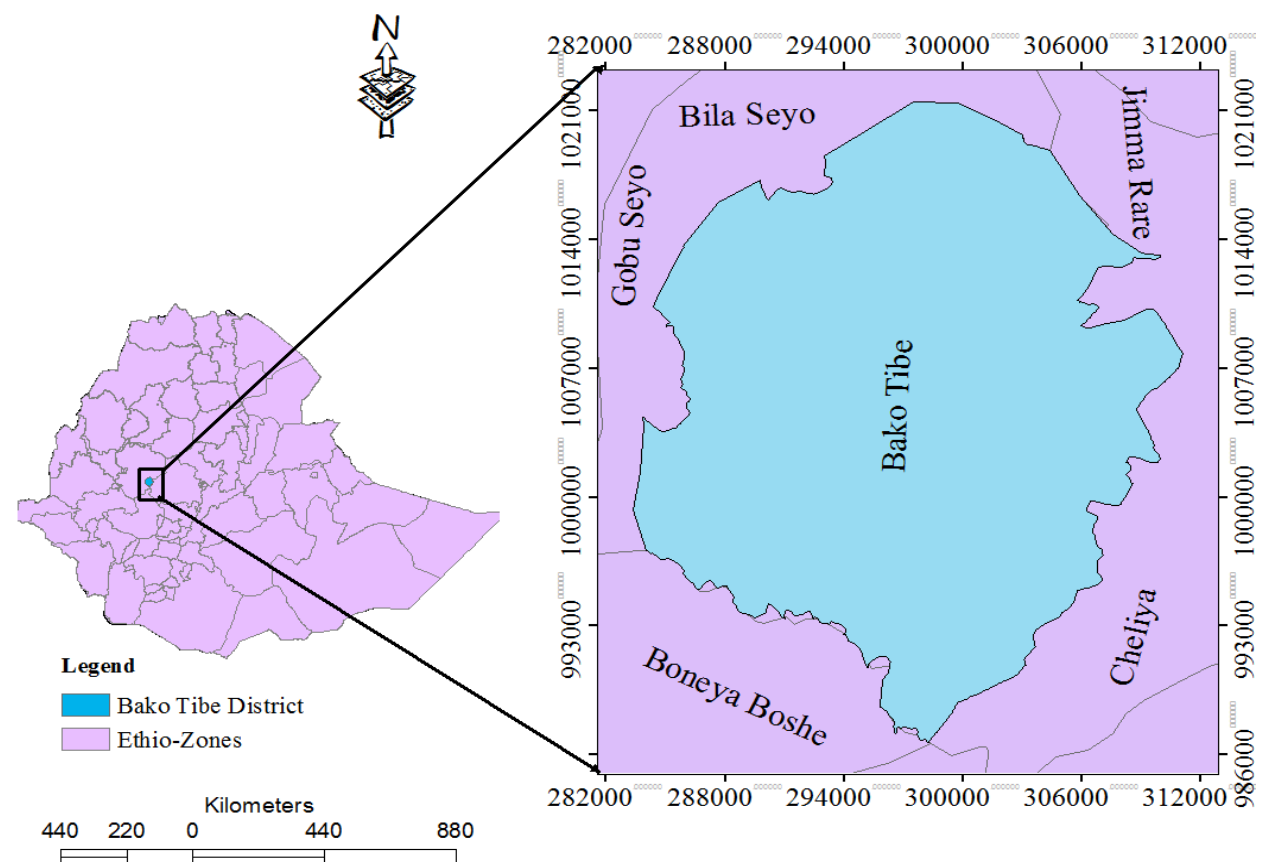

Figure 1. Map of research location

\section{Data collection}

The historical data of climatic variables and yield crops recorded for period of 1989-2018 were collected from secondary sources, and thus, maximum and minimum temperatures and precipitation were acquired from NASA's data portal. They are gridded datasets of rainfall and temperature at $0.50 \mathrm{x} 0.50$-degree resolution. Time series of the selected yield crops, including teff (Eragrostis teff), wheat (Triticum aestivum), barley (Hordium vulgare) and maize (Zea mays), were collected from Bako Research Institute.

\section{Data detection}

The missing values, outliers and autocorrelation and homogeneity tests were performed before data analyses to avoid the internal variation that could affect the absolute values of mean and standard deviation of the variables.

\section{Time scale selection}

Standardized precipitation evapotranspiration index of three-month time scale (SPEI-3) was used to examine agricultural drought index. SPEI3 is a short term of soil moisture and provides a seasonal estimation of agricultural drought when there is insufficient soil moisture to meet the needs of crop plants at particular times (WMO and GWP, 2016). However, SPEI-3 may also be misleading in regions where it is normally dry during any given 3-month period. Therefore, to avoid such problem, we selected four main crops growing months from June-September.

\section{Data analyses}

\section{Trend analyses of temperature and precipitation}

The non-parametric Mann Kendall Test was used to detect time series trended climatic factors. Modified Mann Kendall Test have been used together with the Sen's Slope Estimator for the determination of trend and slope magnitude. Mann Kendall's statistical value of temperature and precipitation was analyzed using R-software. It is defined as the sum of the number of positive 
differences minus the sum of the number of negative difference (Hamed and Rao, 1998; Mondal et al., 2012) and is calculated using this equation.

$$
s=\sum_{k=1}^{n-1} \sum_{j=n+k}^{n} \operatorname{Sign}\left(Y_{j}-Y_{K}\right) \ldots \ldots \ldots \text { Equ. } 1
$$

Where $\mathrm{S}$ is a statistical value that indicates the strength of the climate system to the long-term change of climatic variables. Sign $\left(\mathrm{Y}_{\mathrm{j}}-\mathrm{Y}_{\mathrm{k}}\right)$ is an indicator function that results in the values of 1,0 , or -1 , according to the significance of $\mathrm{Y}_{\mathrm{j}}-\mathrm{Y}_{\mathrm{k}}$, where $\mathrm{j}=2,3,4$ and $\mathrm{k}=1,2$, and then the functions are calculated as follows.

$$
\operatorname{Sign}(\theta)=\left\{\begin{array}{l}
1 \text { if } \theta>0 \\
0 \text { if } \theta=0 \\
-1 \text { if } \theta<0
\end{array}\right.
$$

Where: $\operatorname{sign}(\theta)=\operatorname{sign}\left(Y_{j}-Y_{k}\right)$

A normalized test statistic (Z-score) was computed to check the statistical significance of the increasing or decreasing trends of temperature and precipitation at $0.05\left(\mathrm{Z} \_/ 2= \pm 1.96\right)$ significance levels.

\section{Analyses of agricultural drought indices}

Potential evapotranspiration, water balance and SPEI were analyzed using R-software. Drought indices such as severity, duration and intensity, were analyzed using the outputs from SPEI analyses. The SPEI allows the comparison of drought severity through time and space, and shows better correlation with the yields of crop production, which is strongly affected by soil moisture. It is statistically robust and easily calculated (Begueria et al., 2014). The crucial advantage of SPEI over other drought indices is that it considers the effect of temperature on drought that can identify different types of drought with the context of global warming (Funk et al., 2018). It is designed to take into account both precipitation and potential evapotranspiration in determining drought events.

Potential evapotranspiration was calculated using equation of Hargreaves and Allen (2003). This equation can use maximum and minimum temperatures with specific values of altitudes of the two sites of study. We calculated water balance $(\omega)$ as the difference between precipitation and potential evapotranspiration. The difference is the water surplus or deficit for the analyzed months and is calculated using the equation of Vicente-Serrano et al. (2010).

$$
\omega=P R C P-P E T \ldots \ldots \ldots \ldots \ldots \ldots . . . \ldots q u .2
$$

Where: $\omega$ is water balance, $\mathrm{PRCP}$ is precipitation and PET is potential evapotranspiration.

Finally, SPEI was calculated using R-Software and drought was defined when the values of SPEI fall below zero, i.e. the negative SPEI values are considered 'drought' and positive SPEI values are 'non-drought'. Duration is the length of period, in which the SPEI is continuously negative and it is expressed in terms of consecutive months with no rainfall, and the severity of drought was calculated as follows.

$$
\operatorname{Severity}\left(\sum\right)=\sum_{i=1}^{D} S P E I_{i} \ldots \ldots \ldots . . E q u .3
$$

Where: D is dry duration, in which the SPEI is continuously negative. The intensity of drought is obtained by dividing the drought severity by its duration.

$$
\text { Intensity }(I)=\frac{\sum S P E I}{D} \ldots \ldots \ldots \ldots \ldots \text { Equ. } 4
$$

Based on the procedure proposed by Edwards (1997), the values of SPEI are classified into seven categories, from dry to wet conditions. 'Positive' SPEI-3 value designates greater than zero and 'negative' value designates less than zero (Table 1).

\section{Correlation coefficient analysis}

The Pearson's correlation coefficient analysis was performed to determine the crop yield and agricultural drought indices relationship. The Pearson's correlation coefficient was used to measure the strength of the association between crop yield and agricultural drought indices. It is the most popular method to calculate the direction and degree of the relationship between variables to understand the response of local temperature and rainfall against crop yield. The calculation of the correlation coefficient in this study was performed using the equation below. 


$$
R=\frac{\sum x y}{\sqrt{\left.\sum\left[\sum x^{2}\right)\left(\sum y^{2}\right)\right]}} \ldots \ldots \ldots \ldots \ldots . . E q u .5
$$

Where: $\mathrm{R}$ is correlation coefficient, $\mathrm{X}$ is independent and $\mathrm{Y}$ is dependent variables.

The value of $\mathrm{R}$ is always between -1 and +1 : $1 \leq \mathrm{R} \leq 1$. If $\mathrm{R}=-1$, and then, it is a perfect negative relationship between $\mathrm{X}$ and $\mathrm{Y}$. If $-0.99<$ $\mathrm{R} \leq-0.5$, then it is moderately negative relationship. If $0.49 \leq \mathrm{R}>0$, it is a weak negative relationship. If $\mathrm{R}=0$, it refers to no relationship between the two variables. If $0<\mathrm{R} \leq 0.49$, the relationship is weak positive. If $0.5 \leq \mathrm{R} \geq 0.99$, the relationship is moderately positive and If $\mathrm{R}=+1$, it is a perfect positive relationship between $\mathrm{X}$ and $\mathrm{Y}$ variables. $\mathrm{R}$ square or coefficient of determination shows the percentage variation in $\mathrm{Y}$, which is explained by the entire $\mathrm{X}$ variable together. The coefficient of determination $\left(\mathrm{R}^{2}\right)$ indicates the proportion of the variance in dependent variable, which is predicted from the independent variables. Coefficient of determination is the primary output of regression analysis. Higher R square value is the better, which is between 0 and 1 . It can never be negative since it is a squared value (Gingrich, 2004).

Table 1. Edwards's drought intensity classification

\begin{tabular}{|c|c|c|c|c|}
\hline \multirow{2}{*}{\begin{tabular}{l}
\multicolumn{2}{c}{ Anomaly } \\
Positive
\end{tabular}} & \multicolumn{3}{|c|}{ Range of SPEI values } & \multirow{4}{*}{$\begin{array}{l}\text { Category } \\
\text { Extremely wet } \\
\text { Very wet } \\
\text { Moderate }\end{array}$} \\
\hline & $2<$ & SPEI & $\leq \operatorname{Max}$ & \\
\hline & $1.5<$ & SPEI & $\leq 2$ & \\
\hline & $1<$ & SPEI & $\leq 1.5$ & \\
\hline None & $-1<$ & SPEI & $\leq 1$ & Normal \\
\hline \multirow{3}{*}{ Negative } & $-1.5<$ & SPEI & $\leq-1$ & Moderately dry \\
\hline & $-2<$ & SPEI & $\leq-1.5$ & Severely dry \\
\hline & $\operatorname{Min}<$ & SPEI & $\leq-2$ & Extremely dry \\
\hline
\end{tabular}

Source: Edwards (1997)

\section{RESULTS AND DISCUSSION}

Trends analyses of seasonal and annual temperature and precipitation

Seasonal and annual maximum and minimum temperatures as well as precipitation trends were examined to check the inherent capacity of climate system to change temperatures and preparations of the area of the study.

\section{Seasonal and annual temperature and precipitation trends}

\section{Maximum temperature}

Trend observation confirms that seasonal maximum temperature change has extremely changed during the given time series. Results show that spring, summer and annual maximum temperature significantly got higher $(\mathrm{P}<0.05)$ during time series between 1989 and 2018. The Mann Kendall statistical values (S-scores) of seasonal and annual maximum temperatures were, 126, 164 and 136 for spring, summer and yearly, respectively. These $\mathrm{S}$ values indicate that the intrinsic capacity of the climatic system the area was very strong to change the maximum temperature in the given time bases. The Sen's slopes $(\beta)$ values were $0.26^{\circ} \mathrm{C}, 0.13^{\circ} \mathrm{C}$ and $0.18^{\circ} \mathrm{C}$ for spring, summer and in annual time series, respectively (Table 2). These Sen's slopes indicate the rate of maximum temperature increase per year (Larson and Larson, 1996; Mondal et al., 2012). In this case, temperature is an important limiting factor on yield formation. The optimum range of temperatures is determined for different stages of crop development and would feature prominently in the model functions that express the interactions between climate and yield (Feenstra et al., 1998).

Alike to present findings, many independent researchers reported that the maximum temperature is increasing during three decades in Ethiopia. Maximum air temperature has increased since 1978 almost in the whole country (Shrestha, 1971; Suryabhagavan, 2017). Similarly, the average maximum temperature of North and Central Ethiopia increased from 1901 to 2014 (Asfaw et al., 2018).

\section{Minimum temperature}

Spring, summer and annual minimum temperature showed significantly increasing trend over given time series $(\mathrm{P}<0.05)$. The rates of yearly increment were $0.04^{\circ} \mathrm{C}, 0.02^{\circ} \mathrm{C}$ and 
$0.02^{\circ} \mathrm{C}$ for spring, summer and annual time breaks, respectively. Warmer minimum temperatures expected with climate change and the potential for more extreme temperature events will impact plant productivity. Pollination is one of the most sensitive phenological stages to temperature extremes across all species and during this developmental stage temperature extremes would greatly affect production (Hatfield and Prueger, 2015).

\section{Seasonal and annual precipitation trends}

Unlike the temperature, the significant change of precipitation from 1989 to 2017 was low. Spring and summer seasons and annual precipitation analyses have revealed the insignificantly downwarded trends at P-values; $0.14,0.25$ and 0.54 , respectively. The rates of precipitation change per year, in milimeter were 1.56, 1.94 and 2.19 for spring, summer and annual time breaks, respectively (Table 2 ). Even though precipitation did not substantially changed during the given time series, the decrease per year was higher. These decreasing trends of seasonal and annual precipitation might be associated with various environmental changes, which caused reduction of water availability. The higher temperature reduced rainfall, and increased rainfall variability cut down crop yield and threatened food security in low-income and agriculture-based economies (Meze-Hausken, 2004; Deressa et al., 2011). The large-scale landuse change and deforestation may have contributed to the reduction of rain fed moisture availability (Li et al., 2011; Kenawy et al., 2012).

In line with the present study, some previous studies (Kenawy et al., 2012; Getachew, 2018) scrutinized precipitation trend in North Ethiopia, and reported non-significant decreasing trends of annual and seasonal precipitations.

Table 2. Trends of seasonal and annual temperature and rainfall during the periods of 1989 to 2018

\begin{tabular}{lccc}
\hline \multicolumn{1}{c}{ Times } & S-score & Sen's slope & P-value \\
\hline Spring (MAM) maximum temperature & 126 & 0.26 & $0.05^{*}$ \\
Summer (JJA) maximum temperature & 164 & 0.13 & $0.03^{*}$ \\
Annual maximum temperature & 136 & 0.18 & $0.02^{*}$ \\
Spring (MAM) minimum temperature & 164 & 0.04 & $0.00^{* *}$ \\
Summer (JJA) minimum temperature & 187 & 0.02 & $0.00^{* *}$ \\
Minimum annual temperature & 132 & 0.02 & $0.03^{*}$ \\
Spring (MAM) rainfall & -83 & -1.56 & $0.14^{\text {ns }}$ \\
Summer (JJA) rainfall & -58 & -1.94 & $0.25^{\text {ns }}$ \\
Annual rainfall & -65 & -2.19 & $0.54^{\text {ns }}$ \\
\hline
\end{tabular}

Note: $* *$ and $*$ statistically change of climatic variables at $\alpha=0.01$ and 0.05 respectively, ns $=$ non-significant change, MAM = March, April and May, JJA = June, July and August

\section{Characterization of agricultural drought indices}

The outputs of the SPEI values were characterized for frequency, severity, duration, intensity and trends of agricultural indices.

\section{Frequency}

The number of drought events occurred since 1989 year was widely-ranged in time. Uneven agricultural drought events happened four times for three successive years (2002-2004) and one drought event in 2009. The drought events in 2002 and 2003 were more intensive, occurring during long rainy season. The frequency of drought determined the drought severity and number of people at risk in Ethiopia (Funk et al., 2018). One drought event lowered GDP by $7 \%$ to $10 \%$ and increased poverty by $12 \%$ to $14 \%$ (Makombe et al., 2017) in the country.

\section{Severity}

The harshness of agricultural drought in the area of study was fluctuating in the given time series. The total amounts of severity indices were likely noticed about -23.85 . The highest severe drought indices were identified -8.02 SPEI-3 index value in the 2002 and followed by -6.64 index value. The results of several independent studies have depicted that drought is one of the consequences of global temperature increase or global warming. The mildest heat resulted from an increase in temperature and drought stress can reduce crop yields by 50\% (Lamaoui et al., 2018). The strong role of temperature is increasing heat wave, in which extreme high temperature 
dramatically increases evapotranspiration and aggravates drought stress (Rebetez et al., 2009; Hicke and Zeppel, 2013).

\section{Duration}

The length of drought occurrence is one of the characteristics of most occurring droughts. The total duration of abnormal agricultural drought events was 16 months during 1989-2018. The longest duration of irregular drought was four month long. The longest drought occurred in 2001, 2004 and 2009. The rising global temperature and the change in temperature in Pacific Ocean might increase the duration of agricultural drought. Liu et al. (2018) discussed that the raising global temperature from $1.5^{\circ} \mathrm{C}$ to $2^{\circ} \mathrm{C}$ would increase drought duration from 2.9 months to 3.2 months and the changes in temperatures of the Pacific Ocean contributed to longer duration of drought or excessive rainfall and storms in Ethiopia (USAID, 2015).

\section{Intensity}

Drought intensity is the most important parameter to quantify the strength of agricultural drought. The highest agricultural drought intensity was -2.01 , categorized as extremely dry and followed by -1.66 , categorized as severe dry (Table 3). The higher drought intensity in 2002 was due to seasonal rainfall failure during cropping seasons and it was the most devastating and historic drought that caused critical food shortage for a large proportion of Ethiopian population (Mera, 2018).

Table 3. The duration, severity and intensity of agricultural drought (SPEI-3)

\begin{tabular}{cccccc}
\hline Year & Severity & Duration & Intensity & Edward's category & Description \\
\hline 2002 & -8.02 & 4 & -2.01 & Extremely dry & June-Sept \\
2003 & -6.64 & 4 & -1.66 & Severely dry & June-Sept \\
2004 & -4.88 & 4 & -1.22 & Moderate dry & June-Sept \\
2009 & -4.31 & 4 & -1.08 & Moderate dry & June-Sept \\
\hline Total & -23.85 & 16 & -1.49 & Moderately dry & June-Sept \\
\hline
\end{tabular}

\section{Spatiotemporal agricultural drought indices analyses}

\section{Temporal agricultural drought intensity}

Three month-time scale of SPEI-3 was analyzed to identify the agricultural drought period of time (years) in the study area. The results indicate that 2002, 2003, 2004 and 2009 were the years when the agricultural drought happened, while 1993, 1996, 2010 and 2013 were wetter years (Figure 2).

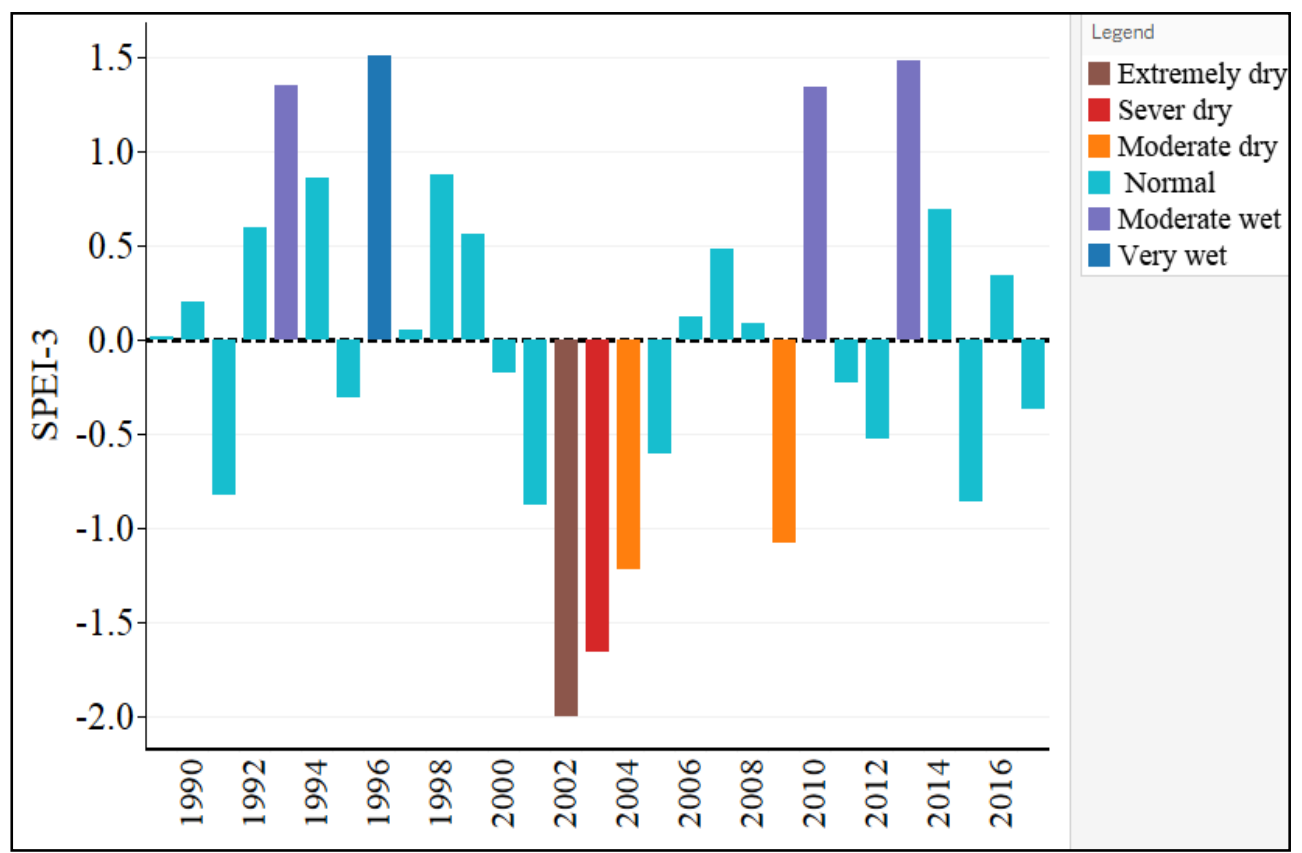

Figure 2. Temporal agricultural drought pattern of Bako Tibe District 
From an agriculture point of view, the June and July rainfalls are very critical for crop sowings, rainfalls in July and August for plant growth and the rainfall of September are important for the flowering and ripening of different crops. However, the deficiency of rain during critical sowing, flowering and ripening period can decrease crop yields and increase food insecurity (Lamaoui et al., 2018).

\section{Spatial agricultural drought intensity}

The special distribution of agricultural drought intensity was analyzed to identify the scope of agricultural drought distribution over the area of the study. The results show that the higher intensity of agricultural drought spell was spread over $36 \%\left(230 \mathrm{~km}^{2}\right)$ of total area of the district. Figure 3 illustrates that distribution of agricultural drought over the study area. The extreme and moderate spatial agricultural drought intensities were spread over location $\mathrm{L}_{1}$ and $\mathrm{L}_{3}$, respectively.

The normal drought category (between 1 and 1) spread over $37 \%\left(235 \mathrm{~km}^{2}\right)$ of the total area of the district. On the other hand, the north part of the district $\left(\mathrm{L}_{2}\right)$ was covered by extremely wet drought indices and accounted $27 \%\left(173 \mathrm{~km}^{2}\right)$ of the total area (Figure 3).

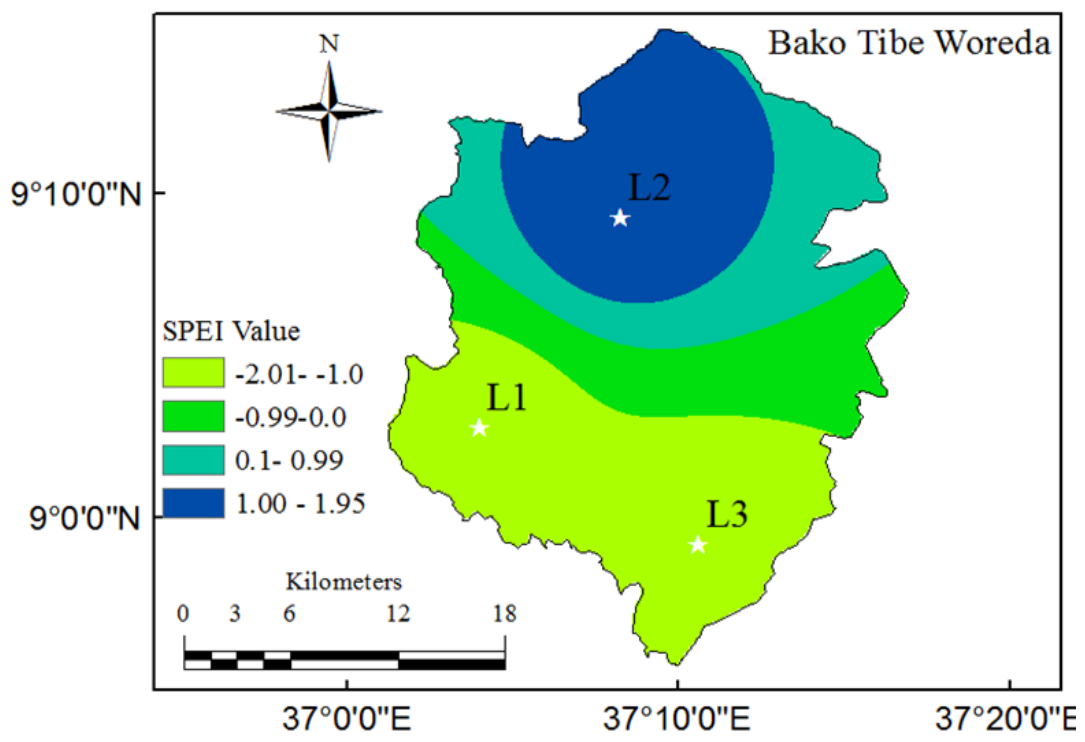

Figure 3. Spatial distribution of agricultural drought intensity

\section{Impacts of agricultural drought on selected crop yields}

To determine the negative impacts of agricultural drought on selected crop yields, the relationship between SPEI-3 and selected crop yields (ton ha ${ }^{-1}$ ) during cropping season (JJAS) was examined. The results revealed that there was a clear phase of relationship between the crop yields and increased agricultural drought indices. All selected crop yield were correlated significantly with SPEI-3 indices at P-values equaling to $0.0034,0.043,0.003$ and 0.001 for teff, wheat, barley and maize, respectively. The values of correlation coefficient between crop yields and SPEI-3 were 0.532, 0.423, 0.534 and 0.556 for teff, wheat, barley and maize, correspondingly. The relationships were moderately positive, SPEI-values increase and the crop yields escalate and vice versa (Figure 4).
However, the increments in crop yields were at the normal ranges of SPEI-3 values; for instance, teff, wheat and Barley crop yields tended to increase up to SPEI value $=+1$ (at maximum value of normal drought index) and declined as drought indices raised beyond +1 (Figure 4A, 4B and $4 \mathrm{C}$ ). Maize crops had a tendency to be interconnected to the higher agricultural drought indices as compared to others crops.

The variances in the crop yields were significantly predicted by the variances of agricultural drought indices. The values of $\left(\mathrm{R}^{2}\right)$ or coefficients of correlation determination were $0.283,0.179,0.285$ and 0.346 for teff, wheat, barley and maize yields, respectively. The total variations of crop yields due to the drought interruptions, in percent, were 28.3, 17.9, 28.5 and 34.6 for teff, wheat, barley and maize, respectively (Figure 4). These variations might be 
due to the combination of high-temperate and water stresses, and increasing duration causes the highest sterility or the decline in fertility of crop plants (Rang et al., 2011).
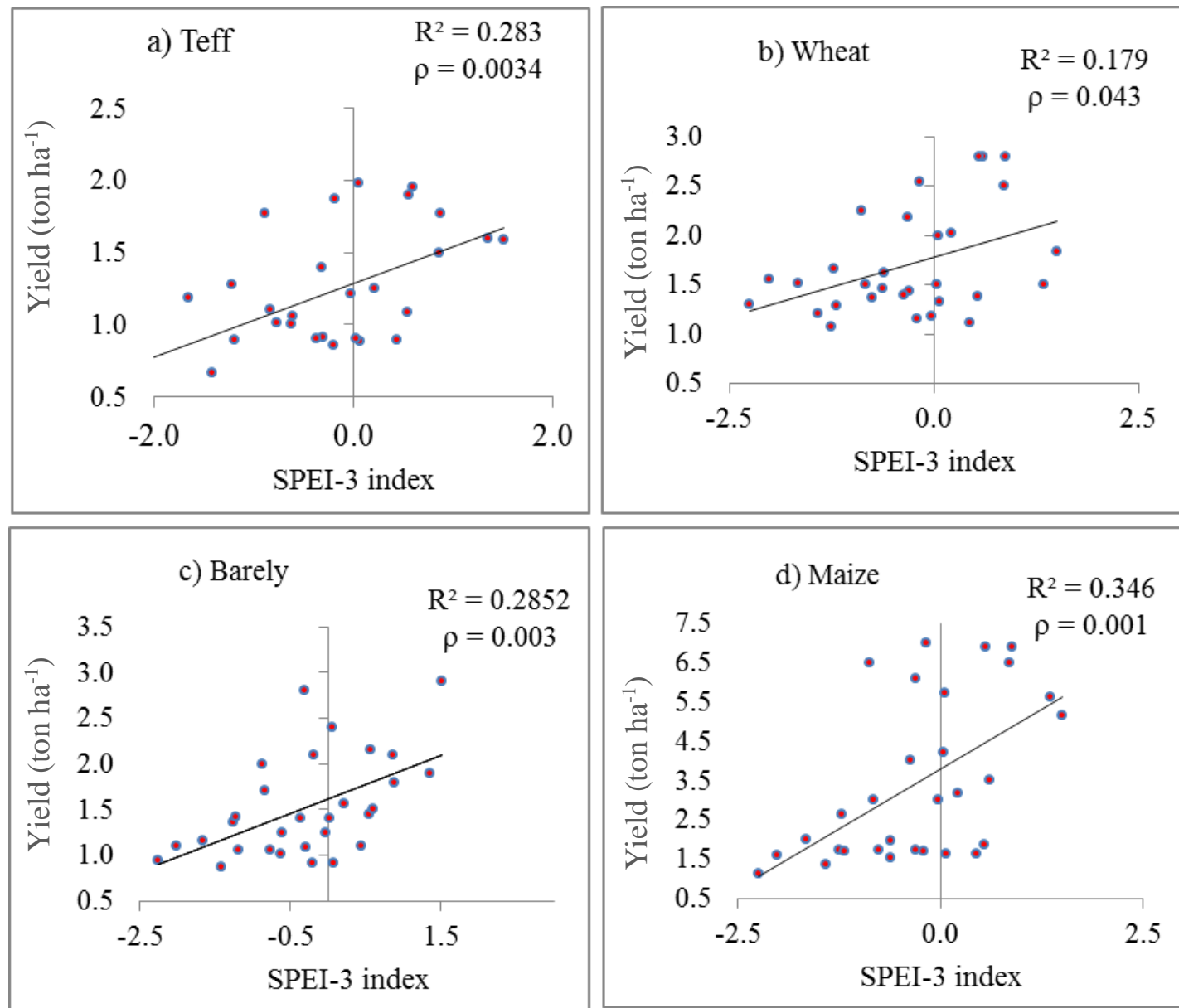

Figure 4. Correlation of agricultural drought indices and selected crop yields

\section{CONCLUSIONS}

The analyses of temperature and precipitation trends of the area disclose vibrant increases of seasonal and annual maximum and minimum temperatures and slight decrease in precipitation. The changes of these climatic variables enforced the climate system to induce moderate to severe agricultural droughts, which happened four times in the last three decades. These robust drought events spatially covered about $36 \%$ total area of the district. The correlation of each crop yield and drought index were moderate positive, when the higher crop yield scores would lead to higher SPEI- 3 scores and vice versa. The values $\mathrm{R}^{2}$ or correlation coefficients of determination in percent were $28.3,17.9,28.5$ and 34.6 for teff, wheat, barley and maize, respectively. The values indicate that the proportion of the variance of each crop yield was due to the variation of drought indices resulted from long increased temperature and decreased precipitation. The map-based results could be used as the guides for the governmental and non-governmental organizations for drought impact mitigation activities in the sites by encouraging farmers to adopt appropriate agricultural technologies, drought tolerant crop varieties and small scale irrigation.

\section{REFERENCES}

Asfaw, A., Simane, B., Bantider, A., \& Hassen, A. (2018). Determinants in the Adoption of Climate Change Adaptation Strategies: Evidence from Rainfed-Dependent Small holder Farmers in North-Central Ethiopia (Woleka Sub-Basin). Environment, Develop ment and Sustainability, 21, 2535-2565. https://doi.org/10.1007/s10668-018-0150-y

Beguería, S., Vicente-Serrano, S. M., Reig, F., \& 
Latorre, B. (2014), Standardized Precipitation Evapotranspiration Index (SPEI) Revisited: Parameter Fitting, Evapotranspiration Models, Tools, Datasets and Drought Monitoring. The International Journal of Climatology, 34(10), 3001-3023. https://doi.org/10.1002/joc.3887

Black, R., Adger, W. N., Arnell, N. W., Dercon, S., Geddes, A., \& Thomas, D. (2011). The Effect of Environmental Change on Human Migration. Global Environmental Change, 21(Supplement 1), S3-S11. https://doi.org/10. 1016/j.gloenvcha.2011.10.001

Brown, M. E., Funk, C., Pedreros, D., Korecha, D., Lemma, M., Rowland, J., Williams E., \& Verdin, J. (2017). A Climate Trend Analysis of Ethiopia: Examining Subseasonal Climate Impacts on Crops and Pasture Conditions. Climatic Change, 142(1-2), 169-82. https:// doi.org/10.1007/s10584-017-1948-6

Calanca, P. (2007). Climate Change and Drought Occurrence in the Alpine Region: How Severe Are Becoming the Extremes?. Global and Planetary Change, 57(1-2), 151-60. https:// doi.org/10.1016/j.gloplacha.2006.11.001

Deressa, T. T., Hassan, R. M., \& Ringler, C. (2011). Perception of and Adaptation to Climate Change by Farmers in the Nile Basin of Ethiopia. Journal of Agricultural Science, 149(1), 23-31. https://doi.org/10.1017/S00218 59610000687

Diffenbaugh, N. S., Pal, J. S., Giorgi, F., \& Gao, X. (2007). Heat Stress Intensification in the Mediterranean Climate Change Hotspot. Geophysical Research Letters, 34(11), L117 06. https://doi.org/10.1029/2007GL030000

Edwards, D. C. (1997). Characteristics of the 20th Century Drought in the USA at Multiple Time Scales. Climatology Report 97-2, Department of Atmospheric Science, Colorado State University, Fort Collins. Retrieved from https ://apps.dtic.mil/dtic/tr/fulltext/u2/a325595.pdf

Egal, F. (2019). Review of The State of Food Security and Nutrition in the World, 2019 Safeguarding Against Economic Slowdowns and Downturns. World Nutrition, 10(3), 95-97. https://doi.org/10.26596/wn.201910395-97

EPA, (2011). The Federal Democratic Republic of Ethiopia Environmental Protection Authority. GEF Portfolio Identification
Document, Addis Ababa, Ethiopia. Retrieved from https://www.thegef.org/sites/default/files /documents/Ethiopia_NPFD_0.pdf

Feenstra, J. F., Burton, I., Smith, J. B., \& Tol, R. S. J. (1998). Handbook on Methods for Climate Change Impact Assessment and Adaptation Strategies. United Nations Environment Programme (UNEP) and vrije Universiteit amsterdam Institute for Environmental Studies, 1-464. Retrieved from http://www.ivm.vu.nl/en/Images/UNEPhandb ookEBA2ED27-994E-4538-B0F0C424C6F6 19FE_tcm234-102683.pdf

Funk, C., Harrison, L., Shukla, S., Pomposi, C., Galu, G., Korecha, D., Husak, G., Magadzire, T., Davenport, F., Hillbruner, C., Eilerts, G., Zaitchik, B., \& Verdin, J. (2018). Examining the Role of Unusually Warm Indo-Pacific SeaSurface Temperatures in Recent African Droughts. Quarterly Journal of the Royal Meteorological Society, 144(51), 360-383. https://doi.org/10.1002/qj.3266

Getachew, B. (2018). Trend Analysis of Temperature and Rainfall in South Gonder Zone, Anhara Ethiopia. Journal of Degraded and Mining Lands Management, 5(2), 11111125. https://doi.org/10.15243/jdmlm.2018.05 2.1111

Gingrich, P. (2004). Chapter 11 Association Between Variables. Introductory Statistics for the Social Sciences. University of Regina. Retrieved from http://uregina.ca/ gingrich/te xt.htm

Hamed, K. H., \& Rao, A. R. (1998). A Modified Mann-Kendall Trend Test for Autocorrelated Data. Journal of Hydrology, 204(1-4), 182-96. https://doi.org/10.1016/S0022-1694(97)0012 $5-\mathrm{X}$

Hargreaves, G. H., \& Allen, R. G. (2003). History and Evaluation of Hargreaves Evapotranspiration Equation. Journal of Irrigation and Drainage Engineering, 129(1), 53-63. https:// doi.org/10.1061/(asce)0733-9437(2003)129:1 (53)

Hatfield, J. L., \& Prueger, J. H. (2015). Temperature Extremes: Effect on Plant Growth and Development. Weather and Climate Extremes, 10, 4-10. https://doi.org/ 10.1016/j.wace.2015.08.001 
Hendrix, C. S., \& Salehyan, I. (2012). Climate Change, Rainfall, and Social Conflict in Africa. Journal of Peace Research, 49(1), 3550. https://doi.org/10.1177/002234331142616 5

Hicke, J. A., \& Zeppel, M. J. B. (2013). Climatedriven Tree Mortality: Insights from the Piñon Pine Die-off in the United States. New Phytologist, 200(2), 301-303. https://doi.org/ 10.1111/nph.12464

Intergovernmental Panel on Climate Change, [IPCC]. (2014). Climate Change 2013 - The Physical Science Basis: Working Group I Contribution to the Fifth Assessment Report of the Intergovernmental Panel on Climate Change. Cambridge: Cambridge University Press. https://doi.org/10.1017/CBO978110741 5324

Kenawy, A. E., López-Moreno, J. I., \& VicenteSerrano, S. M. (2012). Trend and Variability of Surface Air Temperature in Northeastern Spain (1920-2006): Linkage to Atmospheric Circulation. Atmospheric Research, 106, 159180. https://doi.org/10.1016/j.atmosres.2011.1 2.006

Kindu, M., Schneider, T., Teketay, D., \& Knoke, T. (2016). Changes of Ecosystem Service Values in Response to Land Use/Land Cover Dynamics in Munessa-Shashemene Landscape of the Ethiopian Highlands. Science of the Total Environment, 547, 137-147. https://doi. org/10.1016/j.scitotenv.2015.12.127

Lamaoui, M., Jemo, M., Datla, R., \& Bekkaoui, F. (2018). Heat and Drought Stresses in Crops and Approaches for Their Mitigation. Frontiers in Chemistry, 6, 26. https://doi.org/ 10.3389/fchem.2018.00026

Larson, L. L., \& Larson, S. L. (1996). Riparian Shade and Stream Temperature: A Perspective. RANGELANDS, 18(4), 149-52. Retrieved from https://journals.uair.arizona. edu/index.php/rangelands/article/view/11300

Li, Z., He, Y., Wang, C., Wang, X., Xin, H., Zhang, W., \& Cao, W. (2011). Spatial and Temporal Trends of Temperature and Precipitation during 1960-2008 at the Hengduan Mountains, China. Quaternary International, 236(1-2), 127-42. https://doi. org/10.1016/j.quaint.2010.05.017
Liu, W., Sun, F., Lim, W. H., Zhang, J., Wang, H., Shiogama, H., \& Zhang, Y. (2018). Global Drought and Severe Drought-Affected Populations in 1.5 and $2{ }^{\circ} \mathrm{C}$ Warmer Worlds. Earth System Dynamics, 9(1), 267-83. https:// doi.org/10.5194/esd-9-267-2018

Makombe, G., Namara, R. E., Awulachew, S. B., Hagos, F., Ayana, M., \& Kanjere, M. (2017). An Analysis of the Productivity and Technical Efficiency of Smallholder Irrigation in Ethiopia. Water SA, 43(1), 48-57. https://doi. org/10.4314/wsa.v43i1.08

Mera, G. A. (2018). Drought and Its Impacts in Ethiopia. Weather and Climate Extremes, 22, 24-35. https://doi.org/10.1016/j.wace.2018.10. 002

Meze-Hausken, E. (2004). Contrasting Climate Variability and Meteorological Drought with Perceived Drought and Climate Change in Northern Ethiopia. Climate Research, 27(1), 19-31. https://doi.org/10.3354/cr027019

Mondal, A., Kundu, S., \& Mukhopadhyay, A. (2012). Rainfall Trend Analysis by MannKendall Test: A Case Study of North-Eastern Part of Cuttack District, Orissa. International Journal of Geology, Earth and Environmental Sciences, 2(1), 70-78. Retrieved from https:// www.researchgate.net/publication/268438767 _Rainfall_trend_analysis_by_Mann-Kendall_ test_a_case_study_of_North-Eastern_part_of _Cuttack_district_Orissa

Rang, Z. W., Jagadish, S. V. K., Zhou, Q. M., Craufurd, P. Q., \& Heuer, S. (2011). Effect of High Temperature and Water Stress on Pollen Germination and Spikelet Fertility in Rice. Environmental and Experimental Botany, 70(1), 58-65. https://doi.org/10.1016/j.envexp bot.2010.08.009

Rebetez, M., Dupont, O., \& Giroud, M. (2009). An Analysis of the July 2006 Heatwave Extent in Europe Compared to the Record Year of 2003. Theoretical and Applied Climatology, 95, 1-7. https://doi.org/10.1007/s00704-0070370-9

Sheffield, J., \& Wood, E. F. (2008). Projected Changes in Drought Occurrence under Future Global Warming from Multi-Model, MultiScenario, IPCC $\mathrm{AR}_{4}$ Simulations. Climate Dynamics, 31, 79-105. https://doi.org/10.1007 
/s00382-007-0340-z

Shrestha, K. L. (1971). Anomalous Ionospheric Absorption and Microbarometric Activity at Ground Level. Journal of Atmospheric and Terrestrial Physics, 33(2), 213-19. https://doi. org/10.1016/0021-9169(71)90197-8

Smith, M. D. (2011). The Ecological Role of Climate Extremes: Current Understanding and Future Prospects. Journal of Ecology, 99(3), 651-655. https://doi.org/10.1111/j.1365-2745 .2011.01833.x

Suryabhagavan, K. V. (2017). GIS-Based Climate Variability and Drought Characterization in Ethiopia over Three Decades. Weather and Climate Extremes, 15, 11-23. https://doi.org/ 10.1016/j.wace.2016.11.005

USAID. (2015). El Niño in Ethiopia: Uncertainities, Impacts and Decision-Making. Agriculture Knowledge, Learning Documen- tation and Policy (AKLDP) Project, 1-4. Retrieved from http://www.agri-learning-ethio pia.org/wp-content/uploads/2015/09/AKLDPEl-Nino-brief-Sept-2015.pdf

Vicente-Serrano, S. M., Beguería, S., \& LópezMoreno, J. I. (2010). A Multiscalar Drought Index Sensitive to Global Warming: The Standardized Precipitation Evapotranspiration Index. Journal of Climate, 23, 1696-1718. https://doi.org/10.1175/2009JCLI2909.1

World Meteorological Organization, [WMO] \& Global Water Partnership, [GWP]. (2016). Handbook of Drought Indicators and Indices (M. Svoboda and B.A. Fuchs). Integrated Drought Management Programme (IDMP), Integrated Drought Management Tools and Guidelines Series 2. Geneva. Retrieved from https://www.droughtmanagement.info/literatu re/GWP_Handbook_of_Drought_Indicators_a nd_Indices_2016.pdf 